\title{
Can Lotus pedunculatus over-sowing in low-fertility tussock country increase farm resilence?
}

\author{
David R. STEVENS ${ }^{1 *}$, J. Pat GARDEN ${ }^{2}$, Nick GARDEN ${ }^{2}$ and Marie J. CASEY ${ }^{3}$ \\ ${ }^{1}$ Invermay Research Centre, AgResearch, Private Bag 50034 Mosgiel 9053, New Zealand \\ ${ }^{2}$ Avenel Station, Millers Flat, Roxburgh 9572, New Zealand \\ ${ }^{3} P G G$ Wrightson Ltd, 149 Vogel St, Dunedin 9016, New Zealand \\ *Corresponding author: david.stevens@agresearch.co.nz
}

\begin{abstract}
The range of legumes to boost farm productivity in lowfertility hill country are limited. Lotus pedunculatus (Lotus) provides an option when soil $\mathrm{pH}$ is below 5 but is intolerant to severe and regular grazing. However, it can be used at sites that are only grazed occasionally during spring summer and autumn. Oversowing of Lotus pedunculatus has been used to improve 17\% of the total area of Avenel Station, Millers Flat. Measurements of pasture growth and animal production were collected over three years post-sowing, indicating a doubling of pasture production from the native form while providing liveweight gains of 0.135 and $0.75 \mathrm{~kg} / \mathrm{d}$ in lambs and yearling cattle respectively. Systems modelling was used to re-examine the current farm-system configuration to test the possible outcomes from implementing further enterprises that may capture the increased late spring and summer production effectively. Reducing ewe numbers and concentrating on improving lamb survival were the most cost-effective and environmentally effective options. Buying in further finishing lambs to use the summer surplus also improved profitability. Increasing cow numbers was similarly profitable. Increasing ewe numbers also required an increase in winter feed supply and was the least profitable way to capture the benefits. Testing using climatic extreme scenarios demonstrated that the oversowing of Lotus on the higher, wetter tussock country increased the resilience of the farm by providing a buffer during dry summers.
\end{abstract}

Keywords: Environment, farming enterprise, feed supply, low soil fertility, profit, systems modelling.

\section{Background}

Effective use of legumes in hill country is dependent on soil, climatic and grazing conditions. Acidic soils and associated tussock grasslands cover an estimated 2.4 million ha of both North and South Island hill and high country. Aluminium toxicity reduces the

\footnotetext{
An Agricultural Practices article reports on applied work: e.g. practical onfarm demonstration over multiple years of previously published scientific research that describes the situation before and after the application of a new approach.
}

longevity of white clover in these acidic soils (Caradus et al. 2001). However, maintaining soil nutrient status at sufficient levels to ensure a robust white clover component is not sustainable for many hill-country enterprises as remedial quantities of lime and super are too costly to apply in these harsh and often remote environments.

The Lotus species (Lotus pedunculatus and L. corniculatus), hereafter referred to as Lotus, have a unique advantage over other legumes by being very tolerant of both high aluminium levels and low soil fertility (Scott et al. 1985), and could provide high protein feed during the summer and early autumn periods. The ability of Lotus species to tolerate harsh environments has been acknowledged for many years (Keoghan \& Allan 1992) but the use of Lotus as a legume in a pastoral context has never gained a substantial level of adoption and is now very rarely part of a deliberate development strategy. This situation is due mainly to its previous occasional use in very extensive grazing systems where it was not managed properly to best leverage its agronomic needs and attributes (Sheath 1980). Consequently, there is limited information on the integration of the high-quality feed that Lotus can produce in a farm system. Legumes for low-fertility hill country are predominantly perennial in nature, and usually provide more feed in spring and summer, but are dormant during winter. Therefore, it is important to examine how these species change the feed supply and how the farming system may need to change to capture those benefits.

These agronomic considerations are only part of the picture. We also need to consider how the choice of Lotus will meet the needs of the landowner and other stakeholders. How are landscape values like water harvest, visual amenity and biodiversity met? How is the resilience of the business affected? Walker et al. (2010) defined resilience as the capacity of a social ecological system to deal with shocks, the specific nature of that shock to be defined at the time of occurrence. We propose that the key driver of biophysical shock in grazing systems is climatic variation, and that the key indicator of resilience is the ability to limit financial impacts of that variation. 
We used a case-study farm to examine the effect of increases in the area of Lotus on farm productivity and profitability. We also explored other potential opportunities, as the balance of productivity shifts from a predominantly grass-based system to one using Lotus for a feed source in low-fertility hill country. In this study, we used economic farm surplus as the financial indicator to test resilience of the current low-Lotus system with a high-Lotus system under three climatic scenarios.

\section{Approach}

\section{Site characteristics}

Avenel Station $\left(-45.67^{\circ} \mathrm{S}, 169.50^{\circ} \mathrm{E}\right)$ ranges from approximately 200 to $1000 \mathrm{~m}$ a.s.l. in a cool temperate climate (Macara 2015). Rainfall varies from $700 \mathrm{~mm}$ to $900 \mathrm{~mm}$ across this elevation range, with the greatest difference being during summer being approximately $150 \mathrm{~mm}$ at $200 \mathrm{~m}$ a.s.l. and $225 \mathrm{~mm}$ at $1000 \mathrm{~m}$ a.s.l. Temperature again follows the elevational gradient with average winter and summer temperature ranges of $5-1{ }^{\circ} \mathrm{C}$, and $15-11^{\circ} \mathrm{C}$, respectively. These Pallic soils have been modified using fertiliser and lime application on the lower cultivated parts of the farm to have $\mathrm{pH}$ in the 5.6-6.0 range with Olsen-P values of 15-20. Some tussock country on the upper margins of the cultivated area have been modified with fertiliser and lime to register $\mathrm{pH}$ of 5-5.6 and Olsen $\mathrm{P}$ values of 10-15. Higher elevation tussock country is relatively unmodified with $\mathrm{pH}$ of 4.4-5.0 and Olsen-P values of 4-8.

\section{Modelling process}

The following process was used to explore the impacts of over-sowing Lotus in low-fertility hill country. A base model representing the farm in 2017 (Current) was established, incorporating the current areas of Lotus. Previous animal production data (detailed below) were used to develop a model of profitability representing the farm in 2007 (Previous), setting the Lotus area back to the equivalent base production. A model of production with the establishment of further areas of Lotus was developed to represent the farm in 2027 (Potential). The outcomes of this development were explored as either an extension of current practice, or an investigation of an alternative set of viable enterprises. Development costs were calculated and the net value of including Lotus in the model was calculated (further described in the next section). Resilience was tested by developing three pasture growth responses, based on climatic variation, and adjusting the enterprises of the Current and Potential scenarios to test the economic farm surplus generated in each case.

\section{Whole-farm modelling}

The economic value of using Lotus in hill country was evaluated using the Farmax farm systems model (Farmax Pro (Science) version 6.5.3.17, Bryant et al. 2010). This model was used to fit enterprises to the pasture production estimates and pasture production estimated with further development of the Back Hill block being over-sown with Lotus.

A base model was developed first to provide an estimate of potential profitability and productivity in a status-quo environment representing the year 2017 (Current).

\section{Enterprises, stock performance and pasture production}

The farming situation 10 years ago (2007) and at present (2017) at Avenel Station were represented by sourcing records of physical production. The Current model was built using the current enterprises and stock performance from physical and financial records for the 2016-2018 years. These values were used across all models to ensure that returns were all calculated in the same relative terms. The station has an effective grazing area of $1575 \mathrm{ha}$, a total area of $2296 \mathrm{ha}$, running 10,593 stock units (SU), with a base stocking rate of 6.8 SU/ha and a sheep cattle ratio of 72:28.

The farm was divided into six distinct landscape units (Table 1) totalling 1575 ha effective. This area included three highly developed units and three lowinput units, with little soil fertility modification. Pasture production (Table 1) was derived from several sources. The improved paddocks were represented by adapting data from Li et al. (2012). Lucerne production was estimated using temperature, soil moisture deficit and daylength in an algorithm developed by Thompson (2014) from previous research. Improved tussock hillcountry pasture production was previously reported by Cossens (1990) for this site. Caged cut pasture production data collected over three years was used to develop the pasture growth profile for the Lotus block. The pasture production of both the unimproved and oversown hill-country blocks were calculated from grazing day records. Pasture growth patterns from each land parcel are represented in Figure 1.

\section{Financials}

Actual farm expenditure averaged over the years 2016-2018 were used as the main source of farm costs. Labour costs were estimated using the Farm Salaries report (Anon 2018). Scaling of costs for potential and previous scenarios was done using per head costs depending on the expenditure item. Actual expenditure on feed, crops and grazing were also used.

Prices for livestock were the average of those received during the 2016-2018 period. New purchases were quantified using the standard Farmax prices schedules (2016-17). 
Table 1 Landscape units characterised using relative soil fertility at Avenel Station, Millers Flat.

\begin{tabular}{|c|c|c|c|c|c|c|}
\hline \multirow[t]{2}{*}{ Name } & \multirow[t]{2}{*}{ Development } & \multicolumn{2}{|c|}{ Area (ha) } & \multicolumn{3}{|c|}{ Pasture production (kg DM/ha/annum) } \\
\hline & & Total & Effective & Average & Summer wet & Summer dry \\
\hline Paddocks & Cultivated & 764 & 617 & 7,490 & 8660 & 6980 \\
\hline Lucerne & Cultivated & 52 & 52 & 10,610 & No change & No change \\
\hline Oven Hill & High fertility oversown & 144 & 117 & 6,610 & No change & No change \\
\hline Front Hill & Low fertility oversown & 330 & 246 & 2,650 & No change & No change \\
\hline Back Hill & Unimproved & 391 & 276 & 1,030 & No change & No change \\
\hline Lotus & Lotus oversown & 381 & 267 & 2,090 & 1940 & 2495 \\
\hline Other & Forestry, tracks etc & 187 & 0 & & & \\
\hline Total & & 2296 & 1575 & & & \\
\hline
\end{tabular}

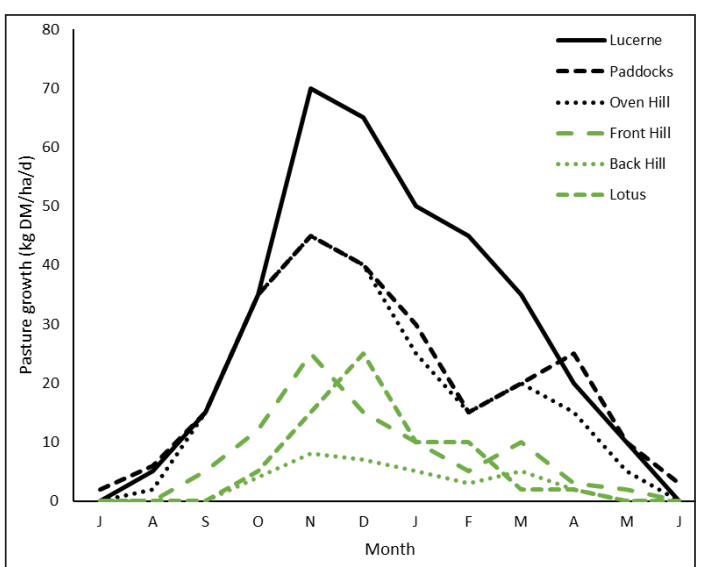

Figure 1 Pasture growth for six land parcels at Avenel Station, Millers Flat.

\section{Stock policies}

The initial stock policies for the base model (Table 2) were based on the current Avenel stock policies. The present ewe policy had 1000 cast for age ewes mated with a terminal sire. Approximately $15 \%$ of lambs were sold store, primarily cull ewe lambs. Prime lambs averaged approximately $17.3 \mathrm{~kg}$ carcase weight, while store lambs averaged $31.2 \mathrm{~kg}$ liveweight. Cows were calved as two-year olds, and all surplus calves were sold after the first winter into the spring market in late October or early November. Ewes were joined on 15 May and cows joined on 28 November.

Potential scenarios used the same potential growth rates of all livestock classes and similar slaughter characteristics, apart from the Potential 3 option.

\section{Scenario development}

Four scenarios were developed based on the data available and past trends (Table 2).

A Previous scenario was developed to provide context for the introduction of Lotus and lucerne into the farm system, giving the opportunity to quantify those impacts.

Three Potential scenarios were developed based on the over-sowing of the remaining unimproved hill country block of 276 ha with Lotus. The Potential 1 scenario used a standard approach of increasing the stocking rate of breeding ewes by 200 . More lambs were finished and less sold store, using the extra summer feed available. No change was made to winter feeding practices or forage cropping (Table 3). The Potential 2 and Potential 3 scenarios explored other options by investigating changes in enterprise, while also reducing winter cropping and adding silage as a supplement. The Potential 2 scenario reduced ewe numbers by 554 and increased lamb survival to achieve a weaning result of $159 \%$. Lamb survival is significantly affected by late gestation nutrition (Kenyon et al. 2011). Changes in lamb survival reported by Johns et al. (2016) were used as a practical demonstration that represented improved ewe nutrition during the winter and early spring. An extra 35 breeding cows and 24 replacement rising-2year-old heifers were added to increase calf numbers. These simulated stocking changes provided a shift away from sheep towards cattle to spread enterprise risk. The extra beef cows also provided a stock class that is more resilient in changing feed supply conditions, while utilising the surplus late spring and summer pasture. On-farm measurements indicated growth rates in rising two-year-old female cattle of $0.75 \mathrm{~kg} / \mathrm{d}$ on the Lotus block. The Potential 3 scenario proposed a different enterprise structure for the farm. Based on the increase in summer feed supply and the previously recorded ewe lamb growth rates of $135 \mathrm{~g} / \mathrm{d}$ on Lotus on this property, Potential 3 proposes a shift away from breeding stock, towards finishing lambs and decreasing ewe breeding numbers by 554 from the Current scenario. Given the location and rainfall of this property, the chosen stock class to purchase was half-bred lambs, to be overwintered, spring shorn and sold into the premium Silere 
Table 2 Stock numbers and animal performance chosen for the Current (2017) Avenel Farmax model, and adjustments made for the Previous ( -10 years), Potential 1, Potential 2 and Potential 3 ( +10 years) scenarios.

\begin{tabular}{|c|c|c|c|c|c|}
\hline \multirow[b]{2}{*}{ Stock } & \multicolumn{5}{|c|}{ Scenario } \\
\hline & Current & Previous & Potential 1 & Potential 2 & Potential 3 \\
\hline Lambing $\%^{1}$ (ewes) & 142 & 130 & 142 & 159 & 159 \\
\hline Lambing \% (hoggets) & 76 & 76 & 76 & 79 & 79 \\
\hline Mixed age ewes & 3,694 & 3,494 & 3,894 & 3,253 & 3,253 \\
\hline Terminal ewes & 1,000 & 900 & 1,000 & 887 & 887 \\
\hline Ewe hoggets total & 1,575 & 1,225 & 1,575 & 1,400 & 1,400 \\
\hline Ewe hoggets mated & 525 & 525 & 525 & 466 & 466 \\
\hline Lambs weaned & 6,933 & 6,060 & 7,217 & 6,658 & 6,658 \\
\hline Lambs purchased & 0 & 0 & 0 & 0 & 2,165 \\
\hline Lambs sold prime & 4,371 & 3,998 & 4,513 & 5,425 & 5,425 \\
\hline Lambs sold store & 837 & 837 & 979 & 501 & 501 \\
\hline Hoggets sold prime & 150 & 100 & 150 & 88 & 1,538 \\
\hline Cows & 250 & 250 & 243 & 285 & 215 \\
\hline Calving $(\%)^{2}$ & 78 & 75 & 78 & 79 & 78 \\
\hline 1-Year Heifer & 106 & 104 & 106 & 134 & 95 \\
\hline 2-Year Heifer & 37 & 30 & 33 & 54 & 30 \\
\hline 1-Year Steer & 110 & 107 & 110 & 135 & 98 \\
\hline 2-Year Steer & - & - & - & - & - \\
\hline Stocking rate & 6.8 & 6.2 & 6.9 & 6.7 & 6.6 \\
\hline
\end{tabular}

${ }^{1}$ Lambs weaned/ewe mated

${ }^{2}$ Calves weaned /cow mated, including rising two-year-olds

Table 3 Changes in policies induced by the changes in pasture production due to Lotus establishment

\begin{tabular}{|c|c|c|c|c|}
\hline \multirow[b]{2}{*}{ Policy } & \multicolumn{4}{|c|}{ Scenario } \\
\hline & Previous & Potential 1 & Potential 2 & Potential 3 \\
\hline Breeding ewe number & -300 & +200 & -554 & -554 \\
\hline Prime lamb sales & -373 & +142 & +698 & +698 \\
\hline Store lamb sales & No change & +142 & -336 & -465 \\
\hline Hogget sales & -50 & No change & -62 & +1388 \\
\hline Replacement numbers & -350 & No change & -175 & -175 \\
\hline Lambing percentage & -12 & No change & +17 & +17 \\
\hline Cropping (ha) & -25 & No change & -17 & -17 \\
\hline Lamb purchases & 0 & 0 & 0 & +2165 \\
\hline Cattle policy & No change & No change & +35 cows & -35 cows \\
\hline Sheep:cattle ratio & $68: 32$ & $73: 27$ & $68: 32$ & $75: 25$ \\
\hline Supplements made & No change & No change & +135 t silage & $+135 \mathrm{t}$ silage \\
\hline
\end{tabular}

market. This approach meant that winter feed crops could also be reduced, de-intensifying the system and potentially reducing environmental impacts. It also provided a potentially more resilient system as the use of trading stock means that climatic-induced variations in pasture growth may be mitigated by livestock sales that have less effect on the base breeding stock. The Potential 3 scenario also assumed that lamb survival increases to achieve a weaning result of $159 \%$, enabled by better feeding of ewes during the winter and early spring. 


\section{Costs of Lotus establishment and maintenance}

The costs of establishing Lotus were taken directly from costs paid out in the 2019 financial year (Table 4). It included seed, fertiliser, sowing and fencing costs related to developing the block. Maintenance costs for the Lotus are also sourced from direct expense records. Investigation into the response of Lotus to fertiliser (DR Stevens unpublished data) indicated that future fertiliser requirements are likely to be minimal due to the low productivity and off-take of product, and so no extra costs have been added for maintenance. The establishment costs have been removed from the yearly expenses and added to a capital investment model to estimate the value of investing in a legumes policy. The persistence of Lotus is determined by grazing intensity which is supported by the fencing costs which allow a 5-7 block rotation over the growing season. A stand life of 10 years has been used in calculations. Previous use provided insight into management requirements and the need for further subdivision. Current blocks are 4 years old and improving. while the cost of the fencing is spread over 30 years.

\section{Economics of legume use}

The benefits of introducing Lotus will take time to be realised. Changes on-farm need to be made to implement potential changes in stock policy. Therefore, an analysis of the impacts must reflect both the introduction of the Lotus, and the future benefits that should accrue. Net present value using potential long-term income was required to better understand the value proposition. This analysis was done using an investment framework with legume establishment costs as an initial capital input, along with capital livestock, as the initial investment. Capital livestock were used as these numbers vary depending on the pasture growth achieved. The economic farm surplus was used as the ongoing income over a ten-year period, estimated to be the average life of a Lotus stand, and then a net present value was calculated, using a discount (interest) rate of 5\%. Net present value was then converted to an annuity to represent the relative annual income (Rendel et al. 2017) to test for the long-term impact of Lotus introduction.

Table 4 Costs of establishing Lotus in 276 ha of hill country tussock.

\begin{tabular}{llr}
\hline Activity & Establishment Cost (total) & Cost $/ \mathrm{ha}$ \\
\hline Seed & $18,000(600 \mathrm{~kg}$ at $\$ 30 / \mathrm{kg})$ & $\$ 65.22$ \\
Oversowing & $10,550(\$ 50 / \mathrm{ha})$ & $\$ 38.22$ \\
Fertiliser & $\begin{array}{l}21,040(240 \mathrm{~kg} / \mathrm{ha}, \\
\text { including application cost) }\end{array}$ & $\$ 76.23$ \\
Fencing & $33,105(4 \mathrm{~km}$ for subdivision at $\$ 9 / \mathrm{m})$ & $\$ 119.94$ \\
\hline
\end{tabular}

\section{Testing resilience}

The resilience of the Current and Potential scenarios, with increased Lotus over-sowing, was tested by comparing financial returns from average pasture growth conditions with pasture growth under summer wet and summer dry conditions. Pasture growth of the Paddocks and Lotus blocks were the only parameters varied. Climate summaries (NIWA 2019) indicate that summer-dry conditions are associated with increased mean temperatures at high elevation. These data were consistent with on-farm experience where soil moisture deficit reduced growth on the Paddocks while higher temperatures promoted growth on the Lotus. Summer-wet conditions create opposite conditions where temperature at high elevation is lower, therefore reducing the growth potential of Lotus, while maintaining higher pasture production at lower elevation on the Paddocks block. Data from Li et al. (2012) were used to supply pasture production estimates for the Paddocks block that represented the two scenarios. Lotus yields were adjusted using the variation present in the pasture growth estimates of Li et al. (2012), applying the opposite relative effect from that present in the responses obtained from the Paddocks block. Final pasture growth inputs are documented in Table 1. Subsequent changes to stocking transactions and nitrogen fertiliser inputs were made to provide feasible outcomes (Table 5) and financial results calculated from those changes.

\section{Results and Discussion}

\section{Pasture cover}

Of the five scenarios, the Previous farm configuration with lower ewe numbers, lower lambing percentage and less crop than the other scenarios had greater cover from May to October than the other scenarios (Figure 2 ). The pasture cover attributes of the other scenarios were similar. Higher pasture cover of the Previous scenario during the winter and early spring would provide greater resilience for that scenario. The shift in the balance of cover to being lower in spring reflects system intensification through increasing breeding ewe numbers in Current and Potential 1 scenarios.

\section{Production}

Our analysis indicated that development over the past 10 years resulted in an increase of stocking rate from 6.2 to 6.8 SU/ha (Table 6). This finding was due primarily to the development of the Lotus block and the increase in winter cropping. This expansion of winter cropping has been both in area, and intensity with the introduction of 25 ha of fodder beet. These increases were required to meet the extra winter-feed demand associated with a traditional approach of increasing breeding stock to utilise extra summer feed. Previous reported studies on 
Table 5 Changes made to the average scenarios for Current and Potential 3 to adjust to pasture growth changes in either dry, warm or wet, cold summer conditions.

\section{Dry}

\section{Current}

Sell surplus ewe lambs store 28 Feb (1029)

Sell remaining maternal ram lambs store 1 March (852)

Sell remaining Terminal Lambs First sale on 31 July to be sold store 16 March (1076) 600 instead of 500

Apply autumn nitrogen (50 units $\mathrm{N} /$ ha on 200 ha of paddocks on 1 April)
Remaining lambs sold on 10 September,

\section{Potential 3}

Sell 150 of purchased store half-breds on 31 March

Bring shearing forward to 20 July

Apply autumn nitrogen ( 50 units $\mathrm{N} /$ ha on 200 ha of paddocks on 1 April)
Wet

Current Potential 3

Keep ewe lambs and sell prime in May instead of

Sell ewe lambs to works at end of June instead of store store in January

Buy 500 store lambs 16 February

Buy 500 Store lambs 15 March

Purchase an extra 1000 lambs 1 March at $29 \mathrm{~kg}$

Take all through the winter selling 600 extras 31 August, rest 10 October

Sell 400 May/June and take 600 through to 31 July and 31 August sale

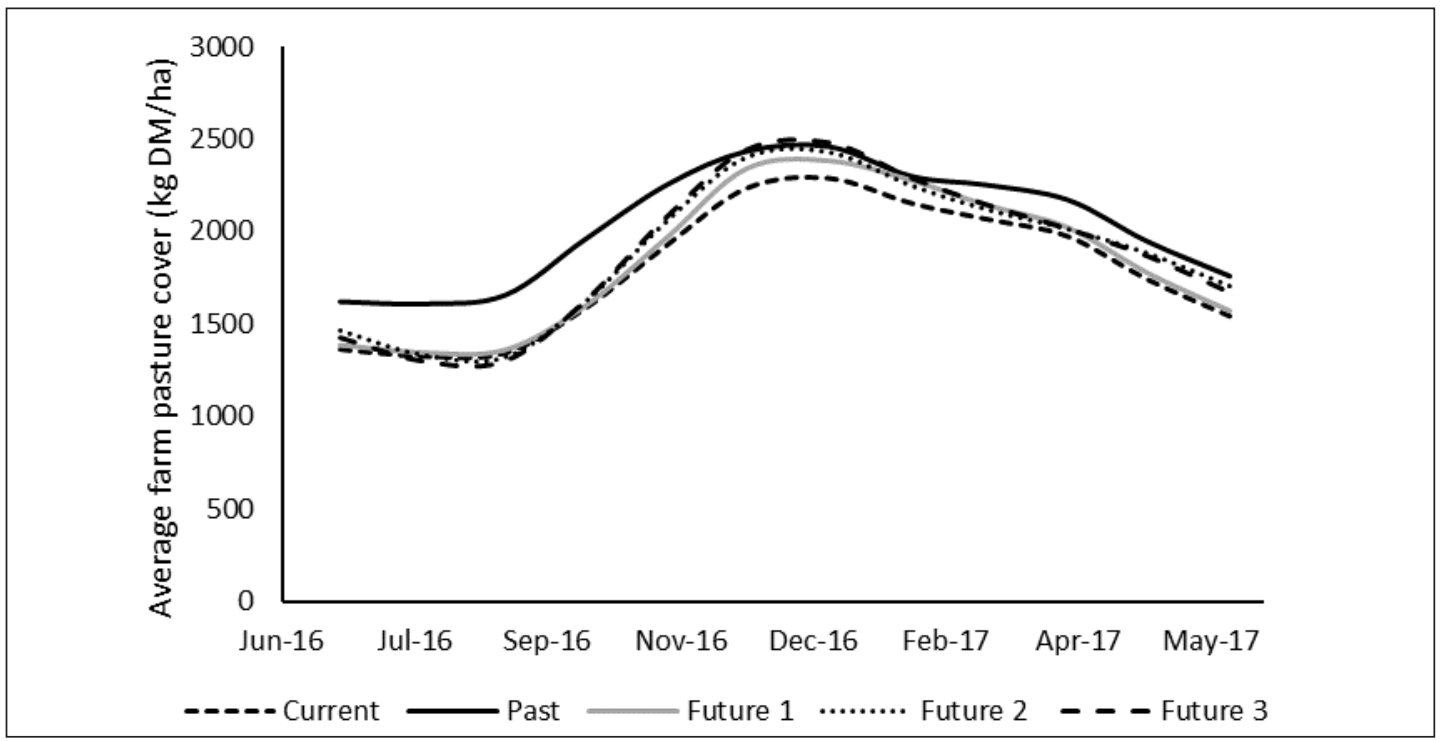

Figure 2 Pasture cover estimates for the five scenarios developed to utilise the production of Lotus from over-sown low fertility hill country.

impacts of the development of tussock country (Allan \& Foran 1994) used extra feed grown to offset hay-feeding requirements. Their approach contrasts with that of the current study and highlights changes in expectations, productivity and whole-farm development that have occurred in the intervening 25 years.

One of the features of the progress over the past 10 years and into the future has been the tendency to greater intensification, mainly through increases in stocking rate. These increases were associated with an expansion of current practice and so have been accompanied by an increase in breeding stock (Table 6). More stock then increased winter feed requirements in line with attempts to capture extra spring and summer growth generated from development of the feed resource using legumes. Studies using lucerne to increase whole-farm productivity and profitability have often captured the value in increased spring productivity (Stevens et al. 2012; Fraser et al. 2016), or changes in overall feed quality (Rendel et al. 2017), thus supporting current 
Table 6 Production parameters for 5 scenarios with and without Lotus over-sowing

\begin{tabular}{|c|c|c|c|c|c|c|}
\hline & & \multicolumn{5}{|c|}{ Scenario } \\
\hline & & Current & Past & Potential 1 & Potential 2 & Potential 3 \\
\hline \multirow[t]{3}{*}{ Area } & Effective area (ha) & 1575 & 1575 & 1575 & 1575 & 1575 \\
\hline & Cropping area (ha) & 71 & 46 & 71 & 54 & 54 \\
\hline & Oversown Lotus area (ha) & 267 & 0 & 543 & 543 & 543 \\
\hline \multirow[t]{4}{*}{ Feeding } & Pasture Eaten (t DM/ha) & 3.39 & 3.03 & 3.45 & 3.54 & 3.43 \\
\hline & Supplements Eaten (t DM/ha) & 0.59 & 0.59 & 0.59 & 0.4 & 0.4 \\
\hline & Total Eaten (t DM/ha) & 3.98 & 3.62 & 4.04 & 3.94 & 3.83 \\
\hline & Nitrogen Boost (t DM/ha) & 0 & 0 & 0 & 0.06 & 0.06 \\
\hline \multirow[t]{3}{*}{ Performance } & Stocking Rate (SU/ha) & 6.8 & 6.2 & 6.9 & 6.7 & 6.5 \\
\hline & Feed Conversion Efficiency (kg DM/ kg Product) & 27.2 & 28.4 & 27.1 & 26.9 & 25.8 \\
\hline & Total meat and wool production (kg/ha) & 137 & 120 & 140 & 137 & 139 \\
\hline \multirow[t]{2}{*}{ Species Ratio } & Sheep (\%) & 71 & 68 & 73 & 68 & 76 \\
\hline & Beef $(\%)$ & 29 & 32 & 27 & 32 & 24 \\
\hline
\end{tabular}

farm enterprise configuration. However, Lotus at high elevations provides feed during late spring and summer, leading to the need for potential changes in enterprise configuration.

An alternative approach is to change the enterprise balance. This situation was represented by one of the Potential scenarios (Potential 3) where winter cropping was reduced and enterprise change shifted in emphasis from breeding/finishing, to a greater degree of finishing. This combination fitted a legume profile more closely and reduced winter feeding costs. It also provided a more flexible policy in the face of more variable climatic conditions, as stock could be bought and sold more readily.

\section{Profitability}

Estimated profitability of the Current scenario is $\$ 34 /$ ha greater than the Previous scenario, based on production records from 10 years ago (Table 7). The increased revenue came mainly from increased lamb sales but was offset by increased costs in all categories, but most notably in winter crop costs.

Developing low-fertility hill country by the oversowing of Lotus increases the amount of feed available during late spring and summer. If a traditional approach of increasing breeding stock is chosen (Potential 1), as is common in this type of hard hill country, then winter feed demand also increases. In the scenario development used here, a practice of decreasing opening pasture cover in spring was chosen, in the first instance, to mitigate the extra winter-feed requirement. This approach provides an element of risk, although the pasture cover profile is similar to the Current scenario.
The feed that will become available on the newly developed Lotus block will be relatively high quality compared with what is available now. The Potential 2 scenario aimed to utilise that advantage by increasing cattle numbers. This scenario also reduced breeding ewe numbers and increased lamb survival as a result of increased feed availability to the ewe flock in late pregnancy. These two factors reduced risk. Firstly, beef cows can buffer variations in late winter feed supply with lower production loss than the ewe flock. Secondly the opportunity to sell calves at weaning or after their first winter provides an extra option to mitigate the risk of drought affecting winter feed supply. If summer-feed supply or quality is compromised then the sale of calves may be used as an offset.

The aim of the Potential 3 scenario was to shift farm management towards enterprises that meet several objectives. First was the change in pasture availability in summer. The provision of relatively high-quality legume means that lamb liveweight gain can be achieved regularly. Thus the use of this feed to finish lambs provides an opportunity. Secondly, this option reduces reliance on winter feed. A reduction in winter-feed requirements can further be achieved by reducing ewe numbers. This provides the opportunity to feed the remaining ewe better in late winter/early spring in the 6 weeks prior to lambing. This is a time when ewe losses often occur, and lamb survival is affected by undernutrition. These options create the potential to increase lamb survival (Johns et al. 2016), thus having little effect on overall lamb numbers born on the property.

The Potential 3 scenario also assumes the farm manager buys half-bred lambs as a finishing option. 
Table 7 Revenue, expenses and economic farm surplus before tax and depreciation of five scenarios incorporating Lotus oversowing into the whole farm system

\begin{tabular}{|c|c|c|c|c|c|c|c|}
\hline & & & \multicolumn{5}{|c|}{ Scenario } \\
\hline & & & Current & Past & Potential 1 & Potential 2 & Potential 3 \\
\hline \multirow[t]{4}{*}{ Revenue } & Sheep & Sales - Purchases & 748179 & 640013 & 777908 & 778143 & 864237 \\
\hline & & Wool & 103252 & 94157 & 108259 & 92782 & 122781 \\
\hline & Beef & Sales - Purchases & 255905 & 255905 & 247582 & 314595 & 216556 \\
\hline & Total Revenue & & 1107336 & 990075 & 1133749 & 1185520 & 1203574 \\
\hline \multirow[t]{18}{*}{ Expenses } & Wages & Wages & 163000 & 163000 & 163000 & 163000 & 163000 \\
\hline & Stock & Animal Health & 51540 & 46248 & 51540 & 49494 & 49494 \\
\hline & & Shearing & 42336 & 38641 & 45438 & 42397 & 46197 \\
\hline & Feed/Crop/Grazing & Conservation & 31500 & 31500 & 31500 & 47700 & 47700 \\
\hline & & Forage Crops & 68315 & 34865 & 68315 & 34865 & 34865 \\
\hline & & Regrassing & 14100 & 10075 & 14100 & 10075 & 10075 \\
\hline & Fertiliser & Fertiliser (Maint) & 116700 & 116700 & 116700 & 116700 & 116700 \\
\hline & & Lime & 8300 & 8300 & 8300 & 8300 & 8300 \\
\hline & & Nitrogen & 0 & 0 & 0 & 21400 & 21400 \\
\hline & Other Farm Working & Weed \& Pest & 4200 & 4200 & 4200 & 4200 & 4200 \\
\hline & & Vehicle Expenses & 40532 & 36351 & 40532 & 38902 & 38902 \\
\hline & & $R \& M$ & 58376 & 52433 & 58376 & 56114 & 56114 \\
\hline & & Freight \& Cartage & 3302 & 2950 & 3302 & 3302 & 8570 \\
\hline & & Electricity & 9995 & 8945 & 9995 & 9572 & 9572 \\
\hline & & Other Expenses & 16000 & 14369 & 16000 & 15377 & 15377 \\
\hline & Standing Charges & Administration Expenses & 22581 & 22581 & 22581 & 22581 & 22581 \\
\hline & & Insurance & 31832 & 31832 & 31832 & 31832 & 31832 \\
\hline & Total Farm Working & pense & 682609 & 622990 & 685711 & 675811 & 684879 \\
\hline \multicolumn{3}{|c|}{ Economic Farm Surplus (EFS) } & 424727 & 367085 & 448038 & 509709 & 518695 \\
\hline & & Interest & 36687 & 32640 & 36403 & 36687 & 46662 \\
\hline \multicolumn{3}{|c|}{ Farm Profit before Tax and depreciation } & 388040 & 334445 & 411635 & 473022 & 472033 \\
\hline
\end{tabular}

This provides extra resilience to the farm in three ways. Firstly, the wool sales are in a different class (mid-micron) and so increases the price per kilogram and changes the market exposure to price fluctuations. Secondly, the lambs are sold into a high-price market, increasing net worth. Thirdly, lamb purchase can be varied depending on procurement arrangements and seasonal pasture growth. This option does introduce a potential animal health issue of foot-rot problems, but a move away from winter crops would help mitigate this, and the choice of half-bred, rather than merino sheep also helps. As for other lamb purchases, an arrangement with another farmer to supply these lambs would ease procurement issues.

Overall, over-sowing the low-fertility hill country with Lotus is a relatively low-cost option. To generate a net present benefit of these options, the capital investment in livestock must also be taken into account, as stock numbers vary across the scenarios (Table 8). Capital value is lowest for the Potential 3 scenario, and highest for Potential 1. Net present value has been calculated using a 10-year period, as an expected stand life for the over-sown Lotus. This analysis separates out the Potential 2 and 3 scenarios from the others. Both these options return $\$ 300 /$ ha from the profit and loss analysis. The difference in net present value represented as an annuity (Table 8) between the Potential 2 and Potential 3 scenarios is $\$ 10 / \mathrm{ha}$ due to the saving in capital investment with a lower ewe stocking rate assumed in Potential 3. Both of these scenarios provide a significant increase in return on the area established than the traditional approach of increasing stocking rate in general (Potential 1).

\section{Resilience testing}

The results, (Table 9), demonstrate the relative financial 
Table 8 Investment analysis of five scenarios incorporating Lotus oversowing using net present value to derive annuity returns over a 10-year investment timeframe, using an interest rate of $5 \%$ for net present value calculations.

\begin{tabular}{lrrrrr}
\hline & \multicolumn{5}{c}{ Scenario } \\
\cline { 2 - 6 } & Current & Previous & Potential 1 & Potential 2 & Potential 3 \\
Stock Capital Value (\$) & $\$ 1,122,271$ & $\$ 1,051,121$ & $\$ 1,133,078$ & $\$ 1,104,716$ & $\$ 977,591$ \\
Area established (ha) & 267 & 0 & 543 & 543 & 543 \\
Establishment cost (\$) & $\$ 58,647$ & $\$ 0$ & $\$ 119,270$ & $\$ 119,270$ & $\$ 119,270$ \\
Net Present Value (\$) & $\$ 1,815,424$ & $\$ 1,531,375$ & $\$ 1,926,188$ & $\$ 2,428,565$ & $\$ 2,548,053$ \\
Annuity (\$/ha) & $\$ 149$ & $\$ 126$ & $\$ 158$ & $\$ 200$ & $\$ 210$ \\
Change in annuity per ha established (\$) & & & $\$ 26$ & $\$ 146$ & $\$ 175$ \\
\hline
\end{tabular}

Table 9

Revenue, expenses and net farm surplus before tax and depreciation expressed in current dollar terms of two scenarios (Current and Potential 3) after adjustments to pasture growth changes in either dry, warm or wet, cold summer conditions to test the resilience of incorporating Lotus oversowing into the whole farm system.

\begin{tabular}{|c|c|c|c|c|c|c|c|c|}
\hline & & & \multicolumn{6}{|c|}{ Scenario } \\
\hline & & & $\begin{array}{l}\text { Current } \\
\text { Average }\end{array}$ & $\begin{array}{l}\text { Current } \\
\text { Wet }\end{array}$ & $\begin{array}{l}\text { Current } \\
\text { Dry }\end{array}$ & $\begin{array}{l}\text { Potential } 3 \\
\text { Average }\end{array}$ & $\begin{array}{c}\text { Potential } 3 \\
\text { Wet }\end{array}$ & $\begin{array}{c}\text { Potential } 3 \\
\text { Dry }\end{array}$ \\
\hline \multirow{4}{*}{$\begin{array}{l}\text { Revenue } \\
\text { (\$/annum) }\end{array}$} & Sheep & Livestock (net) & 748,529 & 813,289 & 699,982 & 864,215 & 914,624 & 856,139 \\
\hline & & Wool & 103,251 & 103,555 & 102,972 & 123,307 & 147,199 & 115,164 \\
\hline & Beef & Livestock (net) & 255,789 & 255,905 & 254,887 & 216,629 & 217,646 & 216,556 \\
\hline & Total $\mathbf{R}$ & & $1,107,569$ & $1,172,749$ & $1,057,841$ & $1,204,151$ & $1,279,469$ & $1,187,859$ \\
\hline \multirow{4}{*}{$\begin{array}{l}\text { Expenses } \\
\text { (\$/annum) }\end{array}$} & & Shearing & 42,321 & 43,471 & 41,365 & 46,221 & 53,111 & 44,124 \\
\hline & & Nitrogen fertiliser & 0 & 0 & 21,400 & 21,400 & 0 & 42,800 \\
\hline & & Interest & 36,687 & 43,469 & 36,687 & 46,662 & 55,176 & 45,130 \\
\hline & \multicolumn{2}{|c|}{ Total Farm Expenses } & 719,281 & 727,213 & 739,725 & 731,566 & 725,569 & 758,536 \\
\hline \multicolumn{3}{|c|}{$\begin{array}{l}\text { Farm Profit before Tax } \\
\text { and depreciation (\$/annum) }\end{array}$} & 388,288 & 445,536 & 318,116 & 472,585 & 553,901 & 429,323 \\
\hline \multicolumn{3}{|c|}{$\begin{array}{l}\text { Farm Profit per ha before } \\
\text { Tax and depreciation (\$/ha }\end{array}$} & 247 & 283 & 202 & 300 & 352 & 273 \\
\hline \multicolumn{3}{|c|}{$\begin{array}{l}\text { Change in farm profit \% } \\
\text { (relative to Current average) }\end{array}$} & 0 & +14.7 & -18.1 & +21.7 & +42.7 & +10.6 \\
\hline \multicolumn{3}{|c|}{$\begin{array}{l}\text { Change in farm profit \% } \\
\text { (relative to Scenario average) }\end{array}$} & 0 & +14.7 & -18.1 & 0 & +17.2 & -9.2 \\
\hline
\end{tabular}

resilience of the Current or Potential 3 systems chosen to utilise summer Lotus production in the face of either summer dry, warm or summer wet, cold conditions (Table 9). Warm, dry summer conditions reduce pasture production on the lower paddock country while increasing Lotus growth on the high-elevation country, changing the balance of feed. Management of Lotus in this environment begins with an accumulation of feed during spring, with no grazing occurring before weaning, which provides a buffer of standing feed that can be utilised during a dry summer. The
Potential 3 scenario utilises the summer production of Lotus by purchasing lambs for finishing, rather than increasing breeding numbers. This approach provides opportunities to vary purchasing decisions based on climatic conditions. As a result, the relative impact of a dry summer on farm profit are reduced compared to the Current scenario which has a greater investment in breeding stock. The shift to purchasing finishing stock also reduces feed requirements in October and November by approximately $20 \%$. This provides opportunities for increased forage conservation and 
rapid recovery of pasture covers if winter conditions require greater utilisation of pasture resources. Extra forage conservation also provides more opportunities for long-term storage of surplus feed, compared to cropping options, further improving resilience.

Beyond the value of an additional feed supply to complement the feed budget, observations suggest that the establishment of Lotus on the higher elevation country on Avenel Station has contributed to wider environmental benefits. The steady incursion of hieracium (Hieracium caespitosum) has been slowed and the enhanced ground cover is contributing to the slowing of water run-off. The higher stocking rate that is achievable through pasture development will also be significant in assisting with the control of wilding conifers as they increasingly impact on upland areas of the Lammerlaw Range.

\section{Conclusions}

The over-sowing of Lotus in low fertility hill country provided an apparent opportunity to increase wholefarm profitability. However, the choice of enterprise to capture the benefits of increases in summer-feed production and quality must be carefully considered. Based on the assumptions made, the results of this analysis suggest that the opportunity to shift hill country farming from breeding/finishing toward greater numbers of finished animals was most profitable.

If increases in breeding stock were chosen as the method of increasing finishing stock numbers then there would be additional pressure on winter feed supply that may compromise reproductive and lactation performance, as well as increasing potential environmental impacts. Shifting towards a purchasing system, or supply arrangements with other farmers, would provide a way of finishing more lambs, and changing lamb supply and wool sales. Using an increase in breeding cow numbers was also an apparent opportunity for a more resilient system, while increasing profitability.

Options that capture the value of increased legume production and quality while restricting or reducing reliance on increases in capital stock may provide longer-term increases in net present value. These outcomes are farm specific, related to current feed supply and demand, as well as current farm enterprises.

\section{ACKNOWLEDGEMENTS}

Funding from Ministry for Primary Industries, Sustainable Farming fund, Beef + Lamb New Zealand, PGG Wrightson Seeds and Grasslanz Ltd.

\section{REFERENCES}

Allan BE, Foran DB. 1994. Developing Tara Hills farm in today's world: the risks and returns. Proceedings of the New Zealand Grassland Association 56: 229-

232. https://doi.org/10.33584/jnzg.1994.56.2110

Anon 2018. Farm Salaries Report. https://www. ruralnewsgroup.co.nz/web-details/markets/2018farm-salaries-report. Accessed June 2019.

Bryant JR, Ogle G, Glassey CB, Lancaster JAS, Garcia SC, Holmes CW. 2010. Description and evaluation of the Farmax Dairy Pro decision support model. New Zealand Journal of Agricultural Research 53: 13-28. https://doi.org/10.1080/00288231003606054

Caradus JR, Crush JR, Ouyang L, Fraser W. 2001. Evaluation of aluminium-tolerant white clover (Trifolium repens) selections in East Otago upland soils. New Zealand Journal of Agricultural Research 44: 141-150. https://doi.org/10.1080/00288233.2001 .9513470

Cossens GG. 1990. Pasture and lucerne production in Otago and Southland. Invermay Technical Report 21. Mosgiel, New Zealand: AgResearch Ltd, 21 p.

Fraser TJ, Stevens DR, Scholfield RW, Nelson BJ, Nelson AJ. 2016. Improved forages to enhance hill country sheep production. Hill Country - Grassland Research and Practice Series 16: 225-232.

Johns C, Johns J, Stevens DR. 2016. Increasing lamb survival and lamb weaning weight through feeding high fecundity crossbred sheep. Hill Country Grassland Research and Practice Series 16: 323-328.

Kenyon PR, Morris ST, Stafford KJ, West DM. 2011. Effect of ewe body condition and nutrition in late pregnancy on the performance of triplet-bearing ewes and their progeny. Animal Production Science 51: 557-564. https://doi.org/10.1080/00288233.2001 .9513470

Keoghan J, Allan B. 1992. Pasture species for tussock grassland landscapes and farming systems. Pp. 3954. In: Guide to Tussock Grassland Farming, Floate MJS (Ed.). Mosgiel, New Zealand: AgResearch Invermay.

Li FY, Vibart R, Dynes RA, Vogeler I, Brown M. 2012. Effects of weather variability on sheep and beef farming in Northern Southland, New Zealand: A modelling analysis. Proceedings of the New Zealand Grassland Association 74: 77-84. https:// doi.org/10.33584/jnzg.2012.74.2887

Macara GR. 2015. The climate and weather of Otago. 2nd ed. NIWA Science and Technology Series 67: 42 p. Wellington, New Zealand.

Rendel JM, MacKay AD, Smale PN. 2017. The value of legumes to a Whanganui hill country farm. Journal of New Zealand Grasslands 79: 35-42. https://doi. org/10.33584/jnzg.2017.79.555

Scott D, Keoghan JM, Cossens GG, Maunsell LA, Floate MJS, Wills BJ, Douglas G. 1985. Limitations to pasture production and choice of species. Grassland Research and Practice Series 3: 9-15. 
Sheath GW. 1980. Effects of season and defoliation on the growth habit of Lotus pedunculatus Cav. Cv. 'Grasslands Maku'. New Zealand Journal of Agricultural Research 23: 191-200. https://doi.org/1 0.1080/00288233.1980.10430786

Stevens DR, Thompson BR, Carruthers A, Wall AJ, Casey MJ, Phiskie R, Young P, Moot DJ. 2012. Understanding the role of spring grazing of lucerne in the Central Otago environment. Proceedings of the New Zealand Grassland Association 74: 69-76. https://doi.org/10.33584/jnzg.2012.74.2886
Thompson BR. 2014. Will the New Zealand deer industry remain competitively profitable in the future? Masters Thesis, Lincoln University. https:// researcharchive.lincoln.ac.nz/handle/10182/6424

Walker B, Sayer J, Andrew NL, Campbell B. 2010. Should enhanced resilience be an objective of natural resource management research for developing countries? Crop Science 50: 10-19. https://doi. org/10.33584/jnzg.2012.74.2886 